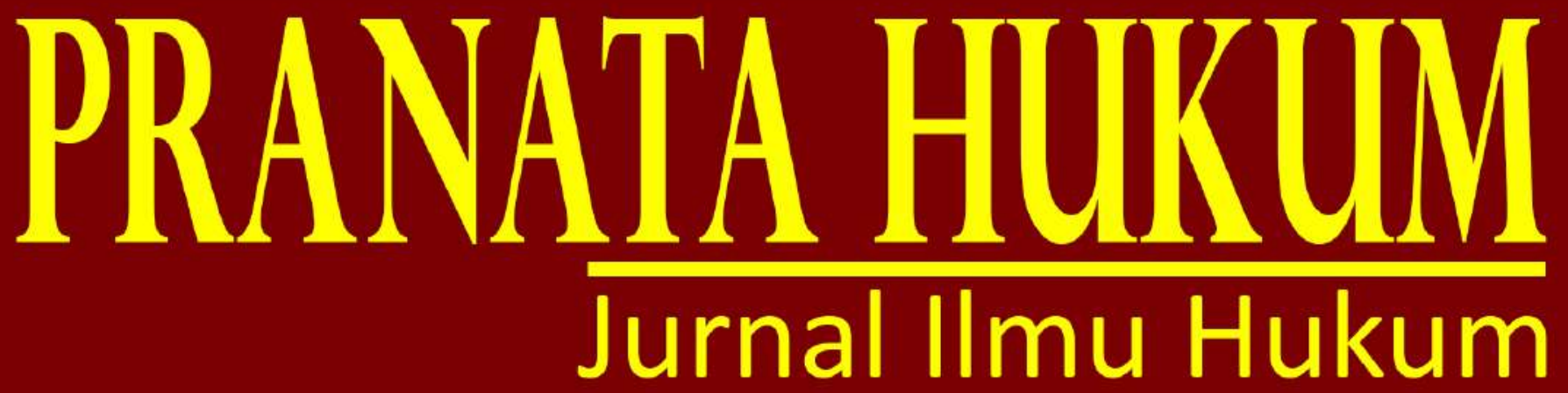

e-ISSN 2685-3213 | p-ISSN 1907-560X

SINERGITAS PEMERINTAHAN DESA DALAM PEMBENTUKAN PERATURAN DESA Anggalana

PENYELESAIAN SENGKETA PERBANKAN BERKAITAN DENGAN PERLINDUNGAN KONSUMEN Dian Herlambang, Muhammad Ridho Wijaya

ANALISIS KOMPARASI ANTARA PERLINDUNGAN PATEN BIASA DENGAN PATEN SEDERHANA BERDASARKAN UNDANG-UNDANG PATEN

Erlina, Melisa Safitri

KONSEPSI NEGARA HUKUM PANCASILA DAN IMPLEMENTASINYA DI INDONESIA Tubagus Muhammad Nasarudin

ANALISIS KEBIJAKAN PEMUNGUTAN RETRIBUSI PELAYANAN PERSAMPAHAN KEBERSIHAN DALAM RANGKA PENINGKATAN PENDAPATAN ASLI DAERAH DI KOTA BANDAR LAMPUNG Pertiwi Agustina RA, Lintje Anna Marpaung, Herlina Ratna Sumbawa Ningrum

ANALISIS KEDUDUKAN PERATURAN DESA PASCA PENGESAHAN UNDANG-UNDANG NOMOR 6 TAHUN 2014 TENTANG DESA DI DESA BADRAN SARI DAN NAMBAH REJO KABUPATEN LAMPUNG TENGAH

Baharudin, Indah Satria, Ramanda Ansori

FANATISME DAN EKSISTENSI NILAI-NILAI DEMOKRASI KADER NAHDLATUL ULAMA KOTA METRO PADA PILPRES 2019

Hendra Irawan, Ika Selviana

PERLINDUNGAN HUKUM TERHADAP PEMENANG LELANG BARANG RAMPASAN NEGARA BERUPA KENDARAAN RODA DUA YANG DIEKSEKUSI DENGAN CARA LELANG OLEH KEJAKSAAN

Okta Vianus Puspa Negara, Zainab Ompu Jainah, S. Tri Herlianto

ANALISIS PERTANGGUNGJAWABAN PELAKU TINDAK PIDANA MENGGANDAKAN SURAT PALSU UNTUK BEKERJA DI PT. GREAT GIANT PINEAPPLE HUMAS JAYA

Helmi Rangkuti, Ketut Seregig, Tami Rusli

MAGISTER HUKUM

UNIVERSITAS BANDAR LAMPUNG

\begin{tabular}{c|c|c|c|l}
$\begin{array}{c}\text { PRANATA } \\
\text { HUKUM }\end{array}$ & $\begin{array}{c}\text { Volume } \\
15\end{array}$ & $\begin{array}{c}\text { Nomor } \\
1\end{array}$ & $\begin{array}{c}\text { Halaman } \\
1-119\end{array}$ & $\begin{array}{l}\text { Bandar } \\
\text { Lampung } \\
\text { Januari } 2020\end{array}$ \\
\hline
\end{tabular}




\section{PRANATA HUKUM}

Jurnal Ilmu Hukum

Magister Hukum

Universitas Bandar Lampung

Terbit Pertama Kali, Juli 2006

Terbit Dua Kali Setahun, Setiap Januari dan Juli

EDITOR IN-CHIEF

Prof. Dr. Lintje Anna Marpaung, S.H., M.H

EDITORIAL BOARDS MEMBERS

Dr. Bambang Hartono, S.H., M.Hum

Dr. Tami Rusli, S.H., M.Hum

Dr. Erlina B, S.H., M.H

Dr. Zainab Ompu Jainah, S.H., M.H

Dr. Zulfi Diane Zaini, S.H., M.H

MANAGING EDITOR

Indah Satria, S.H., M.H

ASSISTANT EDITORS

Yulia Hesti, S.H., MH

Shany Carolina Mawuntu

\section{PENYUNTING AHLI (MITRA BESTARI)}

Prof. Dr. I Gusti Ayu Ketut Rachmi Handayani, S.H., M.M (Universitas Sebelas Maret)

Prof. Dr. I Gede A.B Wiranata, S.H., M.H (Universitas Lampung)

Dr. Nurhadiantomo, S.H., M.Hum (Universitas Muhammdiyah Surakarta)

Dr. Erina Pane, S.H., M.H (UIN Lampung)

\section{Alamat: \\ Kampus B Universitas Bandar Lampung}

Jl. Z.A Pagar Alam No.89 Labuhan Ratu, Bandar Lampung 35142

Telp: 0721-789825 Fax: 0721-770261

Email: jurnal.mh@ubl.ac.id

Jurnal PRANATA HUKUM dimaksudkan sebagai media komunikasi ,edukasi dan informasi ilmiah bidang ilmu hukum. Sajian dan kemasan diupayakan komunikatif melalui bahasa ilmiah.

Redaksi mengundang semua elemen masyarakat ,baik civitas akademika, praktisi , lembaga masyarakat, maupun perorangan yang berminat terhadap bidang hukum untuk berpartisipasi mengembangkan gagasan, wawasan, dan pengetahuan melalui tulisan untuk dimuat dalam jurnal ini. Melalui PRANATA HUKUM diharapkan terjadi proses pengembangan bidang hukum sebagai bagian penting dari rangkaian panjang proses memajukan masyarakat bangsa 


\title{
FANATISME DAN EKSISTENSI NILAI-NILAI DEMOKRASI KADER NAHDLATUL ULAMA KOTA METRO PADA PILPRES 2019
}

\author{
Hendra Irawan ${ }^{1}$, Ika Selviana ${ }^{2}$
}

\begin{abstract}
Fanaticism has become an ordinary phenomenon and has a positive effect on individuals in believing things. However, the fanaticism that arose in the cadre of the Islamic community organization Nahdlatul ulama Metro city related to the presidential election in 2019, not only connects fanaticism with religious beliefs but also against the organization it adheres to. This fanaticism had an impact on the tendency of $\mathrm{NU}$ cadres to choose pairs of presidential candidates based on organizational similarity. The existence of fanaticism is possible to disrupt the existence of democratic values that uphold freedom of choice without pressure from certain individuals or organizations. The type of approach used in this study is qualitative naturalistic, with ethnographic research designs that will find forms of fanaticism of cadres Nahdlatul ulama. The primary data source is aimed at the Nahdlatul Ulama Management and cadres, with data collection techniques in the form of semi-structured interviews and uninvolved observation. From this research, it was found that fanaticism in a number of Nahdlatul Ulama cadres in Metro city is still classified as positive fanaticism. The fanaticism is in the form of support given by spreading positive news of a presidential candidate pair who is supported and dispelling negative news on social media and in the community. The existence of fanaticism in $\mathrm{NU}$ cadres does not at all influence the existence of democratic values because neither the board of directors nor the NU cadre forces their cadres to choose NU ulamas who are included in the presidential candidate pair in the 2019 presidential election.
\end{abstract}

\section{Keywords: Democratic, Fanaticism, and Nahdlatul Ulama}

\section{PENDAHULUAN}

Organisasi Islam yang ada di Indonesia saat ini telah banyak mengalami perkembangan. Tidak sedikit sumbangan yang telah diberikan dalam kehidupan berbangsa dan bernegara. Mereka selalu tampil pada moment penting dalam setiap perubahan politik. Terutama organisasi Islam Nahdhatul Ulama yang menjadi salah satu organisasi Islam terbesar di Indonesia. Dikebanyakan negara dunia Barat, "Pemilu dianggap sebagai lambang sekaligus tolak ukur demokrasi. Hasil

\footnotetext{
${ }^{1}$ Dosen Fakultas Syariah IAIN Metro, hendrairawan@metrouniv.ac.id

2 Dosen Fakultas Ushuluddin, Adab, dan Dakwah IAIN Metro, ika.selviana@metrouniv.ac.id
} 
Pemilu yang diselenggarakan dalam suasana keterbukaan dengan kebebasan berpendapat dan kebebasan berserikat, dianggap agak akurat mencerminkan partisipasi serta aspirasi masyarakat". ${ }^{3}$

Pemilihan umum merupakan ajang bagi masyarakat untuk menuangkan aspirasinya. Hal tersebut dapat diaplikasikan dengan cara berpartisipasi dalam pemilihan presiden yang hampir menjelang tahun 2019 ini sebagai bentuk kepedulian masyarakat terhadap nasib bangsa. Berkaitan dengan pemilihan presiden yang akan dilaksanakan tahun 2019 mendatang, organisasi-organisasi Islam tentu memiliki kecenderungan untuk mendukung pasangan calon presiden tertentu, salah satunya organisasi Nahdlatul Ulama. Hal itu dimungkinkan karena kader dari ormas Islam ini menjadi salah satu kandidat calon wakil presiden.

Sebagai warga Negara yang aktif mengikuti organisasi Islam, bukanlah suatu hal yang mengherankan jika seorang anggota memilih seseorang sesuai dengan yang telah ditetapkan melalui ijtima atau musyawarah para pimpinan ormasnya. Meskipun setiap masyarakat memiliki hak untuk memilih dan menentukan calon presiden sesuai dengan hati nuraninya, sebagai bentuk hak asasi polistik (political Rights), bukan karena hanya bertatbiq (mengikuti) pemimpin ormasnya. Ini sejalan dengan nilai-nilai demokrasi yang berlaku di Indonesia. Nilai demokrasi tersebut adalah sebuah nilai yang membentuk sikap tidak diskriminatif. Kesamaan hak setiap orang sangat dijunjung tinggi oleh demokrasi, itu berarti bahwa tidak ada perbedaan hak antara satu dengan lainnya. ${ }^{4}$

Meskipun seseorang itu berada dalam naungan sebuah organisasi kemasyarakatan, baik sebagai pengurus maupun hanya sebagai anggota. Nilai-nilai demokrasi pada masyarakat sedikit banyak dipengaruhi oleh keaktifannya dalam sebuah organisasi. Hal ini sejalan dengan fenomena yangada di kota Metro. Di sana terdapat kader NU yang cenderung fanatik terhadap organisasi yang diyakininya. Hal itu tampak dengan munculnya komentar- komentar maupun sindiran-sindiran negatif di beberapa media sosial tentang kandidat tertentu untuk membenarkan kandidat pilihan yang didukungnya. Meskipun begitu, ada pula kader NU yang memiliki perbedaan pandangan dalam pemilihan presiden. Kesamaan organisasi yang ada pada pasangan calon presiden tidak membuat seorang kader cenderung memilih pasangan calon tersebut. Oleh karena itu, keberadaan fanatisme dalam organisasi bisa saja mengakibatkan keberadaan nilai-nilai demokrasi tergoyahkan.

Berdasarkan fenomena tersebut, muncul pertanyaan mengenai sejauh mana sebuah fanatisme mempengaruhi pilihan seseorang, apakah terdapat kader NU yang mengesampingkan nilai-nilai demokrasi dalam mendukung pasangan calon presiden yang seorganisasi? dan bagaimana kader NU dalam menyikapi perbedaan pandangan dalam hal pemilihan presiden sebagai bentuk eksistensi nilai-nilai

3 Miriam Budiardjo. 2004. Dasar-dasar Ilmu Politik. Gramedia Pustaka. Jakarta. hlm. 234.

4 Paul Suparno, 2004. Guru Demokratis di Era Reformasi Pendidikan. Gramedia Widiasarana Indonesia. Jakarta. hlm. 37 
demokrasi?. Untuk mendapatkan fakta di lapangan berupa realitas sosial dan persepsi kader NU tentang pemilihan presiden 2019 melalui pengakuan mereka yang mungkin tidak dapat diungkap melalui penonjolan pengukuran formal atau pertanyaan penelitian yang dipersiapkan lebih dulu, jenis pendekatan yang dipakai dalam penelitian ini adalah kualitatif naturalistic, dengan desain penelitian yaitu etnografik. Sumber data primer ditujukan pada Pengurus dan kader Nahdlatul Ulama, dengan teknik pengumpulan data berupa wawancara semi terstruktur dan observasi tidak terlibat.

\section{PEMBAHASAN}

\section{A. Fanatisme}

Fanatisme merupakan sebuah fenomena penting dalam budaya modern,pemasaran, begitu pula dalam realitas pribadi dan sosial masyarakat, hal ini karena budaya saat ini sangat berpegaruh terhadap individu dan hubungan yang terjadi di diri individu melahirkan sebuah keyakinan dan pemahaman berupa hubungan, kesetiaan, pengabdian, kecintaan,dan sebagainya. ${ }^{5}$ Fanatisme yang mungkin muncul pada pilpres 2019 bisa jadi karena adanya hubungan kesamaan organisasi, kesetiaan, pengabdian, maupun kecintaan seorang individu. Perilaku fanatik bisa disebabkan adanya proses interaksi budaya antara individu dengan yang lain, hal tersebut dapat melahirkan suatu bentuk perilaku baru. Terbentuknya Fanatisme bisa disebabkan karena dua halyaitu menjadi penggemar sesuatu hal berupa objek barang atau manusia, dan fanatisme karena keinginan diri sendiri yang terlihatdariberubahnyaperilaku untuk meniru hal yang baru. ${ }^{6}$ Adanya kecintaan terhadap sosok seseorang menciptakan adanya kegemaran yang bisa menjadikan seorang kader ormas cenderung bersikap fanatik.

Menurut Margaretha dalam Reza A.A. Wattimena, Pengaruh sosial dapat mendorong seseorang untuk menjadi fanatik. Keberagaman itu memberikann ancaman bagi kepastian identitas, sehingga seseorang yang dipengaruhi lingkungan sosialnya, justru akan menolak keberagaman, dan semakin keras dan ekstrim dengan identitas tradisionalnya. Fanatisme tidak serta merta muncul begitu saja, melainkan lahir dari proses proses social yang tejadi di masyarakat. ${ }^{7}$ Oleh karenya fanatisme yang muncul pada kader suatu organisasi bisa jadi karena pengaruh lingkungan homogen yang memunculkan tameng agar tak muncul keheterogenan di sekitarnya. Dengan demikian, lingkungan sosial dalam organisasi masyarakat yang sama dapat menimbulkan sikap fanatik berdasarkan suanana

\footnotetext{
5 Seregina, A., Koivisto, E., dan Mattila, P. , Fanaticism-Its Developmentand Meanings in Consumers Lives, Journal of Aalto University School of Economics, 2011, hlm. 12.

6 Ayu Pertiwi Sella. 2013. "Konformitas Dan Fanatisme Pada Remaja Korean Wave (Penelitian Pada Komunitas Super Junior Fans Club Elf "Ever Lasting Friend") Di Samarinda", Journal Psikologi, Vol. 1, No 2, hlm. 157-160.

7 Reza A.A.Wattimena, "Akar-akar Fanatisme", https:// rumahfilsafat.com L2012/11/17/akar-akar-fanatisme/amp/. Diunduh pada 26 Juni 2019
} 
kehomogenan.

Menurut Kiai Ma'ruf, fanatisme dibagi menjadi dua hal, yakni positif dan negatif. Fanatisme positif adalah ketaatan secara total pada ajaran agama. Dan hal itu, boleh dilakukan. Sedangkan fanatisme negatif atau diistilahkan dengan 'asobiyah jama'iyyah (fanatisme jamaah atau golongan) yang menimbulkan kebencian pada golongan atau agama lain, hal itu dilarang. ${ }^{8}$ Berdasarkan pendapat ini, fanatisme organisasi merupakan fanatisme negatif yang seharusnya tidak muncul dari diri kader organisasi. Sebab hal tersebut dapat menimbulkan rasa kebencian terhadap organisasi lain yang tidak sejalan dengan pemikiran, dan visi misi yang diyakini.

Tindakan-tindakan ekstrim, radikal, dan intoleran dalam kehidupan seharihari dapat kita lihat dalam hal fanatisme negatif. Munculnya organisasi masyarakat radikal juga dikarenakan pemahaman akan fanatisme negatif yang dianutnya sehingga dapat menimbulkan terorisme. ${ }^{9}$ Namun demikian, Nahdlatul Ulama sebagai organisasi masyarakat Islam di Indonesia bisa tetap bertahan sampai sekarang dan menjadi yang terbesar di Indonesia tentunya karena tidak membiarkan adanya fanatisme negatif berkembang di dalam organisasinya.

Sejak zaman dahulu di Indonesia, kita mengenal Islam yang mengutamakan perilaku yang mulia untuk mewujudkan rahmatan lil alamin yang selalu diekspos oleh ulama-ulama NU moderat. Diketahui bahwa umat Islam NU juga sangat fanatik dengan ajaran agama Islam, namun segala tindak-tanduk umat Islam NU merupakan bentuk fanatik positif. Mereka senantiasa mengajarkan kedamaian, menyejukan hati dan jiwa. Sebaliknya, umat Islam yang menganut paham khilafah, mereka merasa pemahaman dantindakan mereka paling benar mengenai ajaran Islam. Mereka menganggap Sesama pemeluk agama Islam yang tidak sepaham dengan mereka,munafik, bahkan kafir. Hal ini timbul karena adanya sikap ekstrimis, dengan pembenaran dari mereka sendiri maka mereka dan agama yang dipercayainya menganggap benar tindakan-tindakan radikal. Bahkan mereka akan semakin menunjukan keganasan mereka dengan aksiterorisme jika tindakantindakan mereka ditentang dan dihalangi. ${ }^{10}$

Fanatisme dalam beragama tersebut menjadi contoh bagaimana fanatisme yang berlebihan bisa mengarahkan seseorang ke perilaku negatif. Tak berbeda dengan pesta rakyat yang digelar lima tahun sekali di Indonesia. Pemilihan calon presiden dan wakilnya akan sangat berbeda di tahun 2019, sebab ulama besar yang berasal dari oraganisasi NU turut ambil bagian untuk meraih kemenangan di

8 Ma'ruf Amin, “Fanatisme 'Positif' Dianjurkan!”, diunduh pada 20 Maret 2019 dari https://www.hidayatullah.com/berita/nasional/read/2010/10/05/45015/kh-maruf-aminfanatisme-positif-dianjurkan.html

${ }_{9}$ Covalins, "Fanatisme Negatif dalam Beragama Menimbulkan Pemikiran Ekstrimisme dan Tindakan Radikalisme”, diunduh pada 20 Maret 2019 dari https://seword.com/umum/fanatismenegatif-dalam-beragama-menimbulkan-pemikiran-ekstrimisme-dan-tindakan-radikalisme

10 Ibid. 
PILPRES 2019. Fanatisme organisasi yang menimbulkan kecintaan terhadap sosok ulama di organisasi yang dianut seorang kader bisa jadi mengarah ke fanatisme negatif jika tidak terkontrol dan terawasi dengan baik oleh pihak organisasi.

\section{B. Organisasi Islam Nahdlatul Ulama}

Nahdlatul Ulama dilahirkan pada tanggal 31 Januari 1926 sebagai reprensentatif dari ulama tradisionalis,dengan haluan ideology ahlus sunnah waljamaah tokoh-tokoh yang ikut berperan diantaranya K.H. Hasyim Asy'ari. K.H. Wahab Hasbullah dan para ulama pada masa itu. Di saat kegiatan reformasi mulai berkembang luas, ulama belum begitu terorganisasi namun mereka sudah saling memiliki hubungan yang sangat kuat. Perayaan pesta seperti ulang tahun wafatnya seorang kiai, haul, secara berkala mengumpulkan para kiyai, masyarakat sekitar ataupun para mantan murid pesantren yang kini tersebar luas di seluruh nusantara. ${ }^{11}$

Lahirnya Nahdlatul Ulama tidak dapat dilepaskan dengan upaya mempertahankan ajaran ahlus sunnah wal jamaah (aswaja). Ajaran ini bersumber dari kitab suci Al-qur'an, as-Sunnah, Ijma' ulama, dan Qiyas (kasuskasus yang ada dalam cerita al- Qur'an dan Hadits) seperti yang dikutip oleh Marijan dari K.H. Mustofa Bisri ada tiga substansi, yaitu (1) bidang-bidang hukum-hukum Islam menganut salah satu ajaran dariempat madzhab (Hanafi, Maliki, Syafi'i, dan Hambali), yang pada prakteknya para Kyai NU menganut kuat madzhabSyafi'i.(2)soal tauhid(ketuhanan), menganut ajaran Imam Abu Hasan Al-Asy'ari dan Imam Abu Mansur Al- Maturidzi. (3) bidang tasawuf, menganut dasar-dasar ajaran Imam Abu QosimAl-Junaidi. ${ }^{12}$

Proses konsulidasi faham Sunni berjalan secara evolutif. Pemikiran Sunni dalam bidang teologi bersikap elektik, yaitu memilih salah satu pendapat yang benar. Hasan Al-Bashri (w. 110 H/728) merupakan seorang tokoh Sunni yang terkemuka dalam masalah Qadha dan Qadar perihal manusia, memilih pendapat Qodariyah, sedangkan pada masalah pelaku dosa besar memilih pendapat Murji'ah yang menyatakan bahwa pelaku dosa besar menjadi kufur, hanya imannya saja yang masih fasiq.Pemikiran yang dikembangkan oleh Hasan al-Basri inilah yang kemudian direduksi sebagai pemikiran Ahlus sunnahwaljama'ah. ${ }^{13}$

\section{1) Fanatisme Kader Nahdlatul Ulama Kota Metro Pada Pemilihan Presiden 2019}

Sikap fanatik merupakan sikap yang berlebihan terhadap paham dan ajaran yang dianutnya. Ini merupakan sesuatu yang dibolehkan dalam sebuah paham

\footnotetext{
${ }^{11}$ Masykur Hasyim, 2002. Merakit Negeri Berserakan. Yayasan 95. Surabaya. hlm. 66.

12 Laode Ida. 2004. NU Muda. Erlangga. Jakarta. Hlm. 7

13 Ridwan. 2004. Paradigma Politik NU. Pustaka Pelajar. Yogyakarta. hlm. 95.
} 
atau agama. Terkadang pihak dari luar golongan mengira bahwa seseorang bersikap fanatik terhadap paham atau suatu golongan. Mereka merasa tidak nyaman dan tidak bisa menerima paham golongan tersebut. Padahal orang yang melakukan merasa baik dan biasa terhadap apa yang dilakukannya selama ini karena ia merasa nyaman dengan mengamalkan paham yang dianutnya. Inilah yang sering menyebabkan munculnya kesalahpahaman antara golongan satu dengan yang lain dan menimbulkan sikap radikal terhadap golongan lain. ${ }^{14}$

Dalam konteks pemilihan presiden tahun 2019, fanatisme dalam organisasi masyarakat sering terjadi. Hal ini dikarenakan adanya calon wakil presiden yang berasal dari ormas Islam tertentu. Calon wakil presiden ini adalah seorang yang sangat berpengaruh dan mempunyai kedudukan dan posisi tinggi dalam organisasi masyarakat Islam yang dalam hal ini adalah Nahdlatul Ulama. Berdasarkan wawancara dengan pengurus besar Nahdlatul Ulama, diketahui bahwa adanya fanatisme yang muncul pada kader-kader Nahdlatul Ulama memang sering kali muncul jelang pemilihan presiden tahun 2019 ini. Namun hal tersebut ditanggapi positif oleh pengurus-pengurus pimpinan cabang Nahdlatul Ulama. Menurutnya, fanatisme yang muncul pada kader NU terhadap calon wakil presiden yang berasal dari ormas yang sama merupakan suatu kewajaran. Hal itu merupakan bentuk kecintaan seorang individu dan keyakinannya terhadap organisasi yang dianutnya. ${ }^{15}$

Menurut pengurus PCNU Kota Metro kader Nahdlatul Ulama merupakan seseorang yang mengikuti amalan ataupun kajian ahlu sunnah wal jama'ah. Kader NU yang bersikap fanatik karena kemauan individu atau sebagai bentuk 'sami'na wa ato'na santri terhadap kiayinya adalah bentuk fanatisme positif dan pengurus NU sendiri tidak akan memberikan sanksi, kecuali ada pengurus atau kader yang melakukan orasi terbuka dan memberikan ajakan secara langsung untuk memilih pasangan calon presiden tertentu maka pihak PCNU akan memberikan teguran. ${ }^{16}$ Adanya fanatisme ini memang tidak secara langsung terlihat pada kader- kader Nahdlatul Ulama. Selama pengamatan, sikap fanatik hanya tampak pada status media-media sosial yang beredar di masyarakat atau pada grup-grup media sosial tertentu.

Wawancara yang dilakukan dengan beberapa kader Nahdlatul Ulama di kota Metro menunjukkan bahwa masing-masing kader memberikan bentuk dukungan yang wajar terhadap pasangan calon presiden yanga kan dipilihnya. Bentukbentuk fanatisme negatif tidak tampak jelas berdasarkan proses wawancara. Menurut penelitian pada beberapa warga NU yang disebut dengan nahdiyin,pasangan calon presiden yang akan didukung yaitu nomor urut 1 .

14 Wahyudi Setiawan. 2014., Fanatisme dalam berorganisasi, Jurnal Muaddib, Vol 04, No. 01 Januari-Juni 2014, h. 27.

15 Wawancara dengan Syamsudin Thohir, Mustasyar PCNU Kota Metro pada tanggal 14 April 2019, pukul 16.00 WIB

16 Ibid. 
Pilihan ini disebabkan calon wakil presiden no urut 1 yaitu Ma'ruf Amin adalah seorang ulama yang jujur dan kiayi Nahdlatul Ulama yang amanah. ${ }^{17}$ Ada juga yang memberikan dukungan karena sosok kiayi Ma'ruf yang alim bisa menguatkan kepemimpinan Bapak Jokowi yang santun dan mewakili sosok masyarakat biasa ${ }^{18}$ dan ada pula yang pilihannya didasari alasan untuk mengikuti para ulamanya karena dengan mengikutinya akan selamat dunia danakhirat. ${ }^{19}$

Sikap fanatik yang tampak pada beberapa informan tersebut merupakan bentuk fanatisme positif. Sikap fanatisme yang mereka tunjukan hanya didasari pada kecintaan terhadap ulamanya. Bagi mereka dengan mengikuti dan memilih pemimpin yang merupakan ulama dari organisasi yang sama akan memberikan mereka kebaikan dan keselamatan. Fanatisme positif itu diwujudkan dalam bentuk dukungan berupa memviralkan dan menceritakan latar belakang riwayat hidup dari pasangan calon pilihannya melalui sosial media. Bentuk dukungan yang lain adalah membagikan dan meneruskan informasi mengenai visi dan misi pasangan calon dari organisasi NU melalui whatsapp, facebook, instagram, youtobe, dan lain-lain. Ada pula dukungan yang dilakukan dengan cara mengklarifikasi dan membantah berita-berita bohong/ hoax pasangan calon presiden pilihannya yang tersebar di sosial media maupun masyarakat, serta memviralkan lagu-lagu dukungan di sosial media. Sosial media dianggap menjadi tempat yang sangat tepat untuknya menyampaikan bentuk-bentuk kecintaan yang berlebihan terhadap sosok Kiayi Haji Ma'ruf Amin.

Dalam hal dukungan yang lain pada PILPRES 2019, warga nahdhiyin juga berusaha mempertahankan nilai-nilai demokrasi dengan cara memperkenalkan capaian dan kontribusi pasangan calon presiden pilihannya dan ikut bergabung dengan komunitas-komunitas, maupun relawan-relawan pendukung pasangan calon presiden. Dari beberapa hasil wawancara yang telah dilakukan, peneliti tidak menemui secara langsung perilaku-perilaku fanatik negatif pada narasumber pendukung salah satu calon presiden pada PILPRES 2019. Bentuk dukungan mereka selain berdoa, lebih kepada kecenderungan untuk menyebarkan berita-berita yang positif disosial media ataupun di kalangan masyarakat. Juga mengklarifikasi berita-berita bohong dengan berita-berita yang benar.

Sikap-sikap fanatik dapat terlihat hanya pada status-status media sosial seperti di dinding facebook dan grup-grup tertentu di whatsapp. Bentuk sikap fanatik terlihat pada komentar-komentar sindiran yang dilontarkan terhadap pasangan calon presiden lawan tentang berita yang sedang beredar, atau dengan cara menyebarkan informasi-informasi negatif tentang mereka berbentuk video ataupun berita terpercaya.

17 Wawancara dengan M. Afifuddin, aktivis IPNU di Metro Barat

18 Wawancara dengan Bapak Suwandi, warga nahdiyin, pemain gamelan di Metro Timur

19 Wawancara dengan Mutiara, mahasiswi, di Metro Utara 
Sikap fanatik yang ditemukan pada saat observasi melalui media sosial memang tampak mengarah kepada fanatisme negatif karena selalu menganggap benar segala perilaku dan gerak-gerik pasangan calon yang didukung dan memberikan komentar negatif dan menyalahkan pasangancalon lawan. Namun hal ini, tidak dapat menjadi tolak ukur bahwa dari beberapa kader NU kota Metro memiliki sikap fanatism enegatif, karenaberita yang menyebar melalui media sosial ada kalanya adalah berita bohong dan sebagian individu lah yang membesar-besarkan dengan maksud dan tujuan tertentu.

Para kader Nahdlatul Ulama yang ditemui biasanya lebih banyak membalikkan berita negatif pasangan calon presiden nomor urut 1 dengan katakata sindiran halus terhadap pasangan calon presiden lawan. Fanatisme di sini hanya berupa kecintaan kader nahdlatul Ulama terhadap ulamanya, yaitu kiayi haji Ma'ruf Amin yang sebelumnya juga menjabat sebagai ketua majlis Ulama Indonesia, dan tentunya memiliki wibawa dan kepercayaan yang penuh dari kader-kader Nahdlatul Ulama.

Faktanya, ada beberapa kader yang tampak merespon negatif terhadap sesame kader NU yang tidak memberikan dukungan pada KH. Ma'ruf Amin. Sikap fanatik ini terlihat pada media sosial facebook dengan saling berkomentar berbentuk ejekan, tetapi hal tersebut hanya didapat dari beberapa responden saja yang aktif dalam ikatan pelajar Nahdlatul Ulama, sedangkan responden lain yang merupakan warga nahdiyin yang tidak aktif di organisasi NU hanya berkhidmat kepada kiayi Ma'ruf Amin dengan cara menyebarkan kebaikan-kebaikan tentangnya saja.

\section{2) Eksistensi Nilai-Nilai Demokrasi Kader Nahdlatul Ulama Dalam Menyikapi Perbedaan Pandangan Pada Pilpres2019}

Organisasi Nahdlatul Ulama bukan merupakan partai politik sesuai anggaran dasar dan rumah tangga, namun disadari bahwa banyak kader Nahdlatul Ulama yang terpengaruh dengan latar belakang organisasi masyarakat Islam yang diikutinya dalam pemilihan presiden tahun2019. Tidak dipungkiri kehadiran Kiayi Haji Ma'ruf Amin yang merupakan salah satu Ulama besar Nahdlatu IUlama, memberikan kecenderungan besar bagi banyak kader NU untuk mendukungnya. Meskipun, pengurus Nahdlatul Ulama kota Metro mengatakan bahwa Tidak ada intervensi kepada kader untuk memilih pasangan calon tertentu pada pilpres 2019. NU tetap memberikan kebebasan kepada kader untuk memilih sesuai hati nuraninya.

Pengurus Nahdlatul Ulama kota Metro menyikapi positif, terkait kader yang bersikap fanatik pada pemilihan presiden tahun 2019 ini. Menurutnya, hal itu merupakan implikasi dari pemilihan umum dan tentunya merupakan sikap yang wajar. Banyak kader yang terpengaruh organisasi untuk memilih kiayinya/ 
ulamanya tetapi ada juga yang tidak sependapat. Ada beberapa kader Nahdlatul Ulama kota Metro yang tidak terpengaruh dengan adanya kehadiran Kiayi Haji Ma'ruf Amin sebagai calon wakil presiden. Mereka lebih cenderung memilih pasangan calon presiden dikarenakan sosok calon presidennya, yaitu pasangan calon nomor 2 .

Munculnya fenomena memilih pasangan calon presiden yang tidak berdasarkan dari kesamaan organisasi pada kader Nahdlatul Ulama dikarenakan banyaknya ulama di Indonesia yang memilih PASLON nomor urut 2. Pilihan tersebut tidak hanya dipengaruhi oleh ulama-ulama NU tetapi karena sebagian besar ulama di Indonesia. Salah satu di antara mereka menyebutkan bahwa kepemimpinan PASLON nomor urut 2 dapat memberikan perubahan pada Indonesia. Ada pula warga nahdliyin yang memaparkan bahwa Kiayi haji Ma'ruf Amin lebih pantas menyandang jabatan sebagai ketua MUI bukan wakil presiden dikarenakan menurutnya di bawah dunia perpolitikan siapapun bisa mendapat tekanan yang besar karena posisinya sekalipun ulama besar. Hal itu menunjukkan sikap fanatik dalam wujud yang lain, yaitu kecintaan seseorang terhadap ulamanya melahirkan sikap melindungi dan memilih orang lain yang lebih tepat.

Dari fakta di atas, pengurus Nahdlatul Ulama tidak pernah memberikan intervensi ataupun ajakan secara langsung untuk memilih ulama NU yang dalam hal ini tergabung dalam pasangan calon presiden nomor urut 1. Pengurus Nahdlatul Ulama memberikan kebebasan demokrasi bagi para kadernya untuk menyambut pesta demokrasi yang hanya ditemui 5 tahun sekali. Hak asasi politik kader NU juga tetap terjaga dantidak mendapat gangguan dari organisasi Nahdlatul Ulama. Meskipun begitu, Ada beberapa kader yang mengajak keluarga atau teman untuk mengikuti ulama NU sebagai wujud kepatuhan santri terhadap kiayinya. Hal itu dilakukan hanya berdasarkan nama individu semata, bukan dilakukan atas nama organisasi NU. Pengurus sendiri sudah memberikan pernyataan tegas bahwa siapapun kader yang memberikan orasi untuk memilih PASLON tertentu atas nama organisasi dengan bukti surat resmi dari ketua, katib, wakil, dan sekertaris, maka akan diberikanteguran.

Hal itu menandakan bahwa nilai-nilai demokrasi tetap dipegang teguh dan dipertahankan oleh Nahdlatul ulama dalam pemilihan presiden tahun 2019. Itu terbukti dari kebebasan yang diberikan pada setiap kader untuk memilih dan menyatakan pendapat dalam upaya menyukseskan pesta demokrasi. Meskipun kemungkinan masih ada tekanan yang diberikan oleh individu tertentu untuk memilih ulama yang berasal dari organisasi Nahdlatul Ulama, beberapa kader tetap tidak terpengaruh. 


\section{PENUTUP}

Fanatisme pada kader Nahdlatul Ulama kota Metro hanya berupa sikap fanatik positif dan masih tergolong wajar. Sikap fanatik tersebut hanya berbentuk dukungan berupa menyebarkan berita-berita baik tentang PASLON yang didukung dan menyanggah berita-berita buruk yang tersebar di media sosial. Diketahui bahwa sikap fanatik itu lebih terlihat pada kader Nahdlatul Ulama yang aktif dalam organisasi NU dan mempunyai lingkungan sosial yang homogen. Eksistentsi nilai-nilai demokrasi tetap terjaga pada kader NU kota Metro. Hal itu tampak pada kebebasan yang diberikan kepada warga nahdiyin untuk mendukung PASLON yang sesuai hati nurani tanpa ada tekanan dari Pengurus Ormas NU. Sesama kader NU juga tidak ditemui pemaksaan kehendak untuk sama-sama mendukung kiayi haji Ma'ruf Amin. 


\section{DAFTAR PUSTAKA}

Ayu Pertiwi Sella. 2013. "Konformitas Dan Fanatisme Pada Remaja Korean Wave (Penelitian Pada Komunitas Super Junior Fans Club Elf "Ever Lasting Friend") Di Samarinda", Journal Psikologi, Vol. 1, No 2.

Laode Ida. 2004. NU Muda. Erlangga. Jakarta.

Masykur Hasyim, 2002. Merakit Negeri Berserakan. Yayasan 95. Surabaya.

Miriam Budiardjo. 2004. Dasar-dasar Ilmu Politik. Gramedia Pustaka. Jakarta.

Paul Suparno, 2004. Guru Demokratis di Era Reformasi Pendidikan. Gramedia Widiasarana Indonesia. Jakarta.

Ridwan. 2004. Paradigma Politik NU. Pustaka Pelajar. Yogyakarta.

Seregina, A., Koivisto, E., dan Mattila, P. , Fanaticism-Its Developmentand Meanings in Consumers Lives, Journal of Aalto University School of Economics, 2011.

Wahyudi Setiawan. 2014., Fanatisme dalam berorganisasi, Jurnal Muaddib, Vol 04, No. 01 Januari-Juni 2014.

Reza A.A.Wattimena, "Akar-akar Fanatisme", https:// rumahfilsafat.com L2012/11/17/akar-akar-fanatisme/amp/.Diunduh pada 26 Juni 2019

Ma'ruf Amin, "Fanatisme 'Positif' Dianjurkan!”, diunduh pada 20 Maret 2019 darihttps://www.hidayatullah.com/berita/nasional/read/2010/10/05/ 45015/kh-maruf-amin-fanatisme-positif-dianjurkan.html

Covalins, "Fanatisme Negatif dalam Beragama Menimbulkan Pemikiran Ekstrimisme dan Tindakan Radikalisme", diunduh pada 20 Maret 2019 dari https://seword.com/umum/fanatisme-negatif-dalam-beragamamenimbulkan-pemikiran-ekstrimisme-dan-tindakan-radikalisme 


\section{PEDOMAN PENULISAN \\ JURNAL PRANATA HUKUM}

1. Naskah bersifat orisinil, baik berupa hasil riset atau tinjauan atas suatu permasalahan hukum yang berkembang di masyarakat (artikel lepas), dimungkinkan juga tulisan lain yang dipandang memberikan kontribusi bagi pengembangan ilmu hukum.

2. Penulisan terdiri atas beberapa bab penulisan hasil penelitian terdiri dari $3 \mathrm{BAB}$, yaitu ;

BAB I. PENDAHULUAN (Latar Belakang dan Rumusan Masalah) BAB II. PEMBAHASAN (Kerangka Teori dan Analisis), dan BAB III. PENUTUP (Kesimpulan dan Saran).

3. Tulisan menggunakan bahasa indonesia maupun bahasa inggris yang memenuhi kaidah bahasa yang baik dan benar,tulisan menggunakan bahasa indonesia disertai abstrak dalam bahasa inggris (200 kata) dan Kata kunci, ketentuan ini berlaku sebaliknya.

4. Setiap kutipan harus menyebutkan sumbernya dengan format footnote. Sumber kutipan harus memuat nama pengarang, tahun penerbitan, judul buku, nama penerbit, kota penerbit, dan halaman. Contoh : Bagir Manan. 1994. Hubungan Antara Pemerintah Pusat dan Daerah Menurut UUD 1945. Pustaka Sinar Harapan. Jakarta. 1994, hlm. 19. Untuk artikel dari internet dengan susunan: nama penulis, judul tulisan digaris bawah, alamat website, waktu download/unduh.

5. Naskah harus disertai dengan daftar pustaka atau referensi ,terutama yang digunakan sebagai bahan acuan langsung. Daftar pustaka dan referensi bersifat alfabetis dengan format; nama pengarang, judul buku, nama penerbit, kota terbit, dan tahun penerbitan. Contoh: Bagir Manan. 1994. Hubungan Antara Pemerintah Pusat dan Daerah Menurut UUD 1945. Pustaka Sinar Harapan. Jakarta.

6. Panjang tulisan antara 15-25 halaman, font cambria dengan 1,15 spasi. Dalam hal hal tertentu berlaku pengecualian panjang tulisan.

7. Naskah disertai nama lengkap penulis, alamat e-mail dan lembaga tempat berafiliasi saat ini, dan hal lain yang dianggap penting. 
Jurnal PRANATA HUKUM dimaksudkan sebagai media komunikasi, edukasi, dan informasi ilmiah bidang ilmu hukum khususnya, dan ilmu sosial pada umumnya. Sajian dan kemasan diupayakan komunikatif melalui bahasa ilmiah.

Redaksi mengundang semua elemen masyarakat baik civitas akademika, praktisi, lembaga masyarakat, maupun perorangan yang berminat terhadap bidang hukum untuk berpartisipasi mengembangkan gagasan, wawasan, dan pengetahuan melalui tulisan untuk dimuat dalam jurnal ini.

Melalui PRANATA HUKUM diharapkan terjadi proses pembangunan dan pengembangan bidang hukum sebagai bagian penting dari rangkaian panjang proses memajukan masyarakat bangsa.
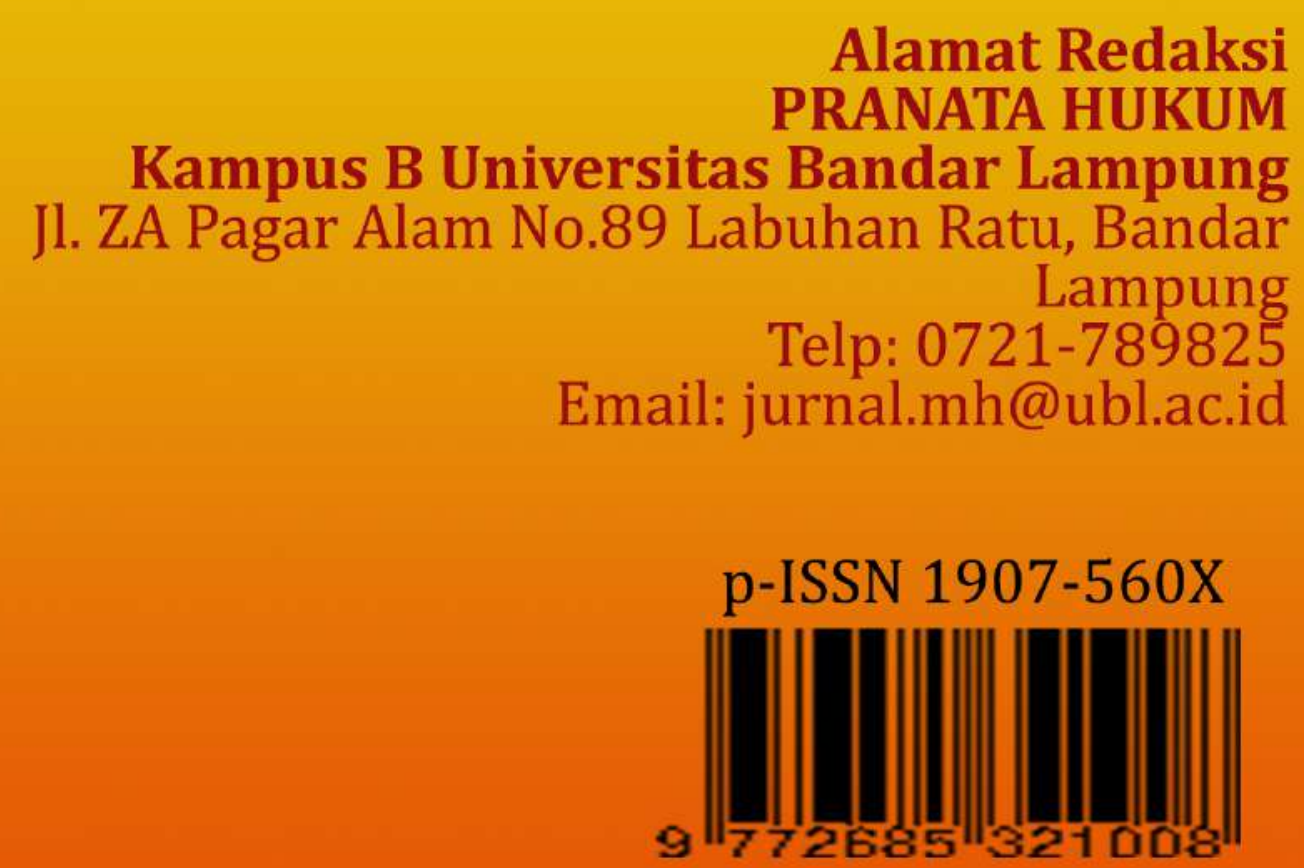